\title{
Review
}

\section{Naturally acquired human immune responses against Helicobacter pylori and implications for vaccine development}

\begin{abstract}
Preface
Helicobacter pylori has been identified as a causative agent of gastroduodenal pathology. Vaccination studies with mouse models have shown that immunisation with bacterial antigens can provide protection against infection, indicating that it may be possible to design vaccines which terminate colonisation by $H$ pylori or prevent it from taking place. Here, we review critically current knowledge of naturally acquired human humoral and cellular immune responses to $H$ pylor $i$ with the aim of delineating questions which should be tackled in order to permit a rational and directed approach to the development of an effective vaccine. We have also reviewed the literature and identified candidate vaccine antigens.
\end{abstract}

\section{Introduction}

$H$ pylori is a Gram negative flagellated bacterium which lives both in the mucus gel layer that coats the gastric mucosa and between the mucus gel layer and the apical surfaces of gastric mucosal epithelial cells. Although it seems to be largely extracellular, some invasion of gastric cells has been reported. ${ }^{1}$ In Western countries, $H$ pylori infection increases from a low prevalence in childhood to about $20 \%$ of people below 40 years of age, ${ }^{2}$ with a steep rise in infection rates to $50 \%$ at age 60 , attributed to increased infection during the Second World War. In underdeveloped countries, acquisition of infection occurs in $10 \%$ of children per annum so that $90 \%$ are infected by their teenage years.

There is a strong association between gastric $H$ pylori infection and gastroduodenal disease. ${ }^{3}$ The presence of the bacterium invariably causes the surrounding mucosa to become inflamed, ${ }^{3-5}$ and the degree of gastritis present is positively correlated with the extent of $H$ pylori colonisation. ${ }^{36}$ Although most people infected with $H$ pylori remain asymptomatic, in some the gastritis progresses to more severe forms of gastroduodenal pathology. Atrophy, characterised by distortion and destruction of the glands, can develop. Furthermore, $H$ pylori induced epithelial cell degeneration can result in ulceration ${ }^{4}$ and $H$ pylori is implicated in 92 and $70 \%$ of all duodenal and gastric ulcers, respectively. ${ }^{2}$ In addition, the presence of $H$ pylori confers a sixfold increased risk of gastric adenocarcinoma and accounts for half of all gastric cancers. ${ }^{2} \mathrm{H}$ pylori is also strongly implicated in the development of gastric $\mathrm{B}$ cell mucosa associated lymphoid tissue (MALT) lymphomas, as shown by their absolute concurrence with $H$ pylori colonisation, ${ }^{27}$ and by tumour regression upon eradication of $H$ pylori. ${ }^{38}$ The development of peptic ulcers, atrophy and MALT lymphomas seems to occur independently, and is mutually exclusive in the case of atrophy and ulcers. However, atrophic gastritis may progress to gastric adenocarcinoma. ${ }^{9}$

The number of neutrophils and eosinophils, normally never found in lamina propria of the stomach, and lymphocytes and plasma cells, which are usually sparse, increases profoundly on infection. ${ }^{510}$ The density of mononuclear cells, but not neutrophils, in infected antral gastric mucosa correlates with the density of $H$ pylori colonisation. ${ }^{11}$ The presence of lymphoid follicles in $H$ pylori induced gastritis further shows that a strong lymphocytic response is elicited by $H$ pylori. These follicles are absent in the healthy stomach and in other gastritides ${ }^{12}{ }^{13}$ and consist of $\mathrm{B}$ cells surrounded by clusters of mostly CD4+ T cells. ${ }^{14}{ }^{15}$ The degree of the lymphoid follicle hyperplasia correlates with the density of bacterial colonisation. ${ }^{13}{ }^{16}$ Gastric B cell MALT lymphomas most likely originate from such follicles. ${ }^{17}$

Despite the vigorousness of this immune response, however, the infection in most cases is not eradicated. As $H$ pylori actively secretes chemotactic products and effectively stimulates pro-inflammatory responses, ${ }^{18-23}$ it may be that the bacterium benefits somehow from the tissue damage caused by the immune response. ${ }^{24}{ }^{25} \mathrm{H}$ pylori may have evolved so as to generate a balance between pro- and antiinflammatory immune responses, inducing and sustaining a steady state of gastritis which is asymptomatic in the majority of hosts. In a small percentage of the population, however, this balance is not achieved, owing perhaps to genetic variation in both the bacterium and host and/or environmental factors, and thus pathology ensues as a result of the excessive activity of the macrophage, neutrophil and eosinophil effectors of mucosal damage. ${ }^{1-23}$

Specific antibody responses may be critical for protective immunity against extracellular bacteria like $H$ pylori, and $\mathrm{T}$ cells are well known for their capacity to induce and modulate the functions of effector cells (e.g., B cells, macrophages, neutrophils, and eosinophils) important in the control or eradication of extracellular bacteria. An effective vaccine against $H$ pylori should thus aim to induce a specific, non-pathogenic humoral and $\mathrm{T}$ cell response. This article reviews critically current knowledge of naturally acquired human immunity to $H$ pylori. Attention will be focused on areas of controversy or uncertainty which should be resolved to allow delineation of the appropriate responses to be induced by vaccination. The antigen specificity of the humoral response is also assessed and candidate vaccine antigens are identified.

\section{Helicobacter pylori specific B cell responses}

H PYLORI INDUCES LOCAL AND SYSTEMIC ANTIBODY RESPONSES

$H$ pylori specific $\operatorname{IgG}, \operatorname{Ig} M$ and $\operatorname{IgA}$ antibodies are present at high titres in inflamed gastric mucosae of infected patients ${ }^{6} 2627$ and antibody coated bacteria can be seen in virtually all biopsy samples of gastritis associated with infection. ${ }^{6}$ The degree of opsonisation correlates with the frequency of local plasma cells. ${ }^{28}{ }^{29}$ Specific serum IgG is also produced, and is the most sensitive marker of infection ( $>90 \%$ sensitivity and specificity). ${ }^{30} \mathrm{~A}$ drop in titre is a reli-

Abbreviations used in this review: APC, antigen presenting cell; CTL, cytotoxic T cell; Hsp, heat shock protein; IFN, interferon; IEL, intraepithelial lymphocytes; IL, interleukin; LFA, leucocyte function associated antigen; LPL, lamina propria lymphocytes; MALT, mucosa associated lymphoid tissue; NUD, non-ulcer dyspepsia; PBMC, peripheral blood mononuclear cells; TCR, T cell receptor; TGF, transforming growth factor. 
able indicator of successful eradication. ${ }^{31}{ }^{32} \mathrm{H}$ pylori specific IgG and IgA responses are not, however, skewed towards a particular isotype. ${ }^{33}$ A single report also found significant levels of $H$ pylori specific IgE in serum samples and on basophils of infected, but not uninfected, patients with chronic gastritis. ${ }^{34}$

SPECIFIC ANTIBODIES MAY LIMIT BACTERIAL GROWTH AND REDUCE BACTERIAL TOXICITY

Oral administration of antibodies directed against $H$ pylori eradicates infection in animal models ${ }^{35}$ and limited evidence exists suggesting that IgA antibodies in particular may contribute to controlling the bacterial population in humans. Infants of mothers with high titres of anti-H pylori IgA have a significant delay in acquisition of infections. ${ }^{36}$ In addition, in a study of asymptomatic subjects, the density of $H$ pylori, disease activity score, and rate of peptic ulceration were all significantly increased in subjects with low specific serological IgA titres compared with those with high titres. ${ }^{37}$ Furthermore, although IgA deficient individuals are no more susceptible to $H$ pylori infection, ${ }^{38}$ they have a notably increased risk of developing gastric malignancies, ${ }^{39}$ which may be a consequence of $H$ pylori overgrowth unchecked by IgA. Opsonisation by IgG and IgM also promotes in vitro phagocytosis and killing by neutrophils, ${ }^{40}$ and antibodies may modulate bacterial pathogenicity by neutralising essential virulence factors. ${ }^{41}$

SPECIFIC ANTIBODIES MAY CONTRIBUTE TO PATHOGENICITY More evidence exists suggesting that $H$ pylori induced antibody responses might be pathological. Specific mucosal IgG in the presence of soluble bacterial antigen promoted neutrophilic cytotoxicity to cultured Vero cells. ${ }^{42}$ Moreover, serum samples from most infected patients specifically crossreact with gastric mucosa but not with other tissues. ${ }^{43}$ Mice immunised with $H$ pylori, but not other bacteria, also developed such antibodies. ${ }^{43}$ In addition, mice bearing a hybridoma secreting a $H$ pylori specific monoclonal antibody shown to be crossreactive with both human and murine gastric mucosa developed stomach pathology, whereas mice bearing non-crossreactive hybridomas did not. ${ }^{44}$ Autoantibody levels correlated strongly with histological inflammatory scores.

$H$ pylori derived lipopolysaccharide, which contains Lewis antigens also occurring on human gastric epithelium, may induce some autoreactive antibodies. ${ }^{45}$ Gastric inflammatory scores and associated atrophy correlated significantly with the expression of Lewis antigens on autologous $H$ pylori strains. ${ }^{44}$ Furthermore, the bacteria were significantly more likely to express the same type of Lewis antigen as their host, ${ }^{46}$ suggesting that bacteria with alike Lewis phenotypes are selected in vivo. $H$ pylori specific autoantibodies may also be directed against protein epitopes expressed on gastric parietal cells and intrinsic factor. ${ }^{47}$ Such autoantibodies are also typically found in human autoimmune gastritis. ${ }^{49}$

SPECIFICITIES OF THE HUMORAL IMMUNE RESPONSE

Table 1 summarises studies investigating the specificity of local and systemic humoral responses to $H$ pylori antigens by immunoblot, ELISA or ELISPOT. ${ }^{26}{ }^{50-63}$ Most immunoblot studies did not identify the subject antigens so these are grouped according to molecular weight and possible identity. Donors are grouped according to disease status: gastroscopy (unspecified complications), peptic ulcer, non-ulcer dyspepsia (NUD), gastric carcinoma, and asymptomatic. The term dyspepsia refers to discomfort in the upper abdominal area which may be caused by various pathologies. All groups are subdivided according to $H$ pylori carriage. With the exception of two studies ${ }^{54}$ which did not distinguish between isotypes, all studies looking at systemic responses focused on IgG, whereas both IgA and IgG responses in gastric mucosae were examined.

A single study examining gastric mucosal humoral responses by ELISPOT found $H$ pylori specific B cells in infected but not in uninfected individuals. ${ }^{55}$ Serum and mucosal antibodies from infected subjects, regardless of disease status, also always exhibited more frequent responses to $H$ pylori antigens. ELISA and ELISPOT studies revealed very low reactivity in uninfected subjects, but, notably, immunoblot studies often showed considerable responsiveness in these people-for example, to $\mathrm{p} 46 / 47$ and heat shock protein (Hsp) 60. Protein denaturation during immunoblotting may reveal cryptic epitopes recognised by crossreactive antibodies.

Several antigens seem to be reproducibly immunodominant in infected people, including three unidentified proteins of approximately 19, 25 and $35 \mathrm{kDa}$, urease A and B subunits, flagellin, Hsp60, flagellar sheath protein, and CagA. These proteins or a combination thereof are thus interesting candidate antigens for vaccines in humans, particularly those which can induce protective immunity in animals, namely urease, ${ }^{64-70} \mathrm{Hsp} 60^{71}$ and CagA. ${ }^{69} 72$

One study, not included in table 1 because frequencies of antigen recognition were not assessed, used two dimensional immunoblotting followed by $\mathrm{N}$-terminal sequencing of spots recognised by pooled IgG of infected endoscopy patients but not by uninfected donors. ${ }^{73}$ This study identified over $30 \mathrm{H}$ pylori proteins specifically recognised by infected patients, demonstrating the power of this technology. Most of those proteins were expressed by all eight strains analysed. In another study, although substantial antigenic diversity in $H$ pylori isolates was found, the 25 , $31,56,60$ and $84 \mathrm{kDa}$ proteins were highly conserved. ${ }^{74}$

Several reports have attempted to associate recognition of $H$ pylori proteins with disease. One protein, CagA, is strongly implicated in ulcer disease as it is recognised more frequently in patients with ulcers than in those with NUD. ${ }^{52}$ In addition, $75 \%$ of patients with peptic ulcer, NUD or gastric carcinoma, but only $25 \%$ of asymptomatic infected subjects, recognised Hsp60. ${ }^{57}$ In contrast, lower serum responses to p33, p59 and p66 by $H$ pylori positive patients with gastric carcinoma have been found. ${ }^{56}$ These data implicate particular antigenic $H$ pylori phenotypes in disease. However, whether the antibody responses to the pathology associated antigens contribute to the pathology itself is not known. With regard to CagA, it is now understood that CagA+ strains induce more interleukin (IL) 8 than CagA- ones (reviewed by Crabtree and Farmery ${ }^{75}$ ), and thus CagA- specific antibodies are more likely to simply reflect the presence of CagA+ bacteria. Moreover, immune responses to bacterial Hsps could be protective rather than pathogenic. ${ }^{76}$

\section{$\mathrm{T}$ cell responses to $\mathrm{H}$ pylori}

EPITHELIAL CELLS AND PROFESSIONAL ANTIGEN PRESENTING CELLS MAY ACTIVATE $H$ PYLORI SPECIFIC T CELLS

The conditions in the inflamed stomach support the activation of $\mathrm{T}$ cells as the molecules required for $\mathrm{T}$ cell activation are increased on epithelial cells, monocytes, and dendritic cells. Although gastric epithelia do not normally express HLA-DR, ${ }^{77}$ chronic gastritis in general is associated with a rise in epithelial HLA-DR expression, with significantly higher expression in infected than in uninfected gastritic mucosae. ${ }^{578} 79$ The HLA-DR positive areas occur in close proximity to mononuclear cell infiltrates. ${ }^{80}$ Human gastric epithelial cell lines and freshly isolated epithelial cells from gastric biopsy samples also constitutively express both B7-1 and B7-2 and can provide $\mathrm{T}$ cell costimulation in vitro. ${ }^{81} \mathrm{~B} 7-2$ is upregulated by stimulation with $H$ pylori, 
Table 1 Recognition of Helicobacter pylori antigens by different patient groups and asymptomatic donors

\begin{tabular}{|c|c|c|c|c|c|c|c|c|c|c|c|c|}
\hline \multirow{3}{*}{$\begin{array}{l}\text { Antibody } \\
\text { isotype/method/ } \\
\text { location }\end{array}$} & \multirow{3}{*}{$\begin{array}{l}M W \\
(k D a)\end{array}$} & \multirow[b]{3}{*}{ Identity } & \multicolumn{9}{|c|}{ Per cent specific recognition by subjects ${ }^{a}$} & \\
\hline & & & Gastroscop & & Peptic ulcer & $N U D$ & & Gastr & cinoma & Asympt & natic & \\
\hline & & & $\mathrm{Hp}^{+}$ & $H_{p-}$ & $\mathrm{Hp}^{+}$ & $\mathrm{Hp}^{+}$ & $H p^{-}$ & $\mathrm{Hp}_{\mathrm{p}}$ & $H p-$ & $\mathrm{Hp}^{+}$ & $H p^{-}$ & Reference \\
\hline IgG/ELISA/S & 13 & HspA & 40 & 0 & & & & & & & & 50 \\
\hline $\mathrm{IgG} / \mathrm{IB} / \mathrm{S}$ & 14 & NI & 97 & 49 & & & & & & & & 51 \\
\hline $\mathrm{IgG} / \mathrm{IB} / \mathrm{S}$ & 14 & NI & $37^{\star}$ & 12 & & & & & & & & 52 \\
\hline $\mathrm{IgG} / \mathrm{IB} / \mathrm{S}$ & 15 & NI & $85^{\mathrm{b}}$ & 60 & & & & & & & & 53 \\
\hline $\mathrm{IgG} / \mathrm{IB} / \mathrm{S}$ & 16 & NI & $49^{\star}$ & 2 & & & & & & & & 52 \\
\hline $\mathrm{IgG} / \mathrm{IB} / \mathrm{S}$ & 19 & NI & 59 & 0 & & & & & & & & 51 \\
\hline $\mathrm{IgG} / \mathrm{IB} / \mathrm{S}$ & 19 & NI & $64^{\star \star \star}$ & 5 & & & & & & & & 53 \\
\hline All/IB/S & 19 & NI & 100 & 0 & & & & & & & & 54 \\
\hline $\mathrm{IgG} / \mathrm{IB} / \mathrm{S}$ & 25 & NI & 54 & 0 & & & & & & & & 51 \\
\hline $\mathrm{IgG} / \mathrm{IB} / \mathrm{S}$ & 25 & NI & $45^{\star \star}$ & 5 & & & & & & & & 53 \\
\hline All/IB/S & 25 & NI & 100 & 0 & & & & & & & & 54 \\
\hline IgA/ESP/L & 26 & NI & & & A:33 & & & & & A: 67 & A:0 & 55 \\
\hline IgA/ESP/L & 26 & NI & & & C:0 & & & & & C:50 & C:0 & 55 \\
\hline IgG/ESP/L & 26 & NI & & & A: 0 & & & & & A: 17 & A:0 & 55 \\
\hline IgG/ESP/L & 26 & NI & & & C:0 & & & & & C:17 & C:0 & 55 \\
\hline $\mathrm{IgG} / \mathrm{IB} / \mathrm{S}$ & 27 & NI & $67^{\star \star \star}$ & 5 & & & & & & & & 53 \\
\hline $\mathrm{IgG} / \mathrm{IB} / \mathrm{S}$ & 28 & NI & & & & & & $66^{\mathrm{b}}$ & 45 & $65^{\mathrm{b}}$ & 37 & 56 \\
\hline $\mathrm{IgG} / \mathrm{IB} / \mathrm{S}$ & 30 & NI & $82^{\star \star \star}$ & 15 & & & & & & & & 53 \\
\hline $\mathrm{IgG} / \mathrm{IB} / \mathrm{S}$ & 30 & NI & $63^{\star}$ & 30 & & & & & & & & 52 \\
\hline $\mathrm{IgG} / \mathrm{IB} / \mathrm{S}$ & 30 & $\mathrm{U} / \mathrm{A}$ & 91 & 0 & & & & & & & & 51 \\
\hline $\operatorname{IgA} / \mathrm{ESP} / \mathrm{L}$ & $30+67$ & $\mathrm{U}$ & & & A:64 & & & & & A:91 & A:0 & 55 \\
\hline IgA/ESP/L & $30+67$ & $\mathrm{U}$ & & & C: 67 & & & & & C:78 & $\mathrm{C}: 0$ & 55 \\
\hline IgG/ESP/L & $30+67$ & $\mathrm{U}$ & & & $\mathrm{A}: 22$ & & & & & A:64 & A:0 & 55 \\
\hline IgG/ESP/L & $30+67$ & $\mathrm{U}$ & & & $\mathrm{C}: 56$ & & & & & $\mathrm{C}: 56$ & $\mathrm{C}: 0$ & 55 \\
\hline $\mathrm{IgG} / \mathrm{IB} / \mathrm{S}$ & 67 & $\mathrm{U} / \mathrm{B}$ & 90 & 0 & & & & & & & & 51 \\
\hline $\operatorname{IgA} / \mathrm{IB} / \mathrm{L}$ & 31 & NI & & & $80^{\mathrm{b}}$ & 75 & & & & & & 26 \\
\hline $\mathrm{IgG} / \mathrm{IB} / \mathrm{S}$ & 33 & NI & & & & & & $61^{\mathrm{b}}$ & 54 & $100 \dagger$ & 37 & 56 \\
\hline $\mathrm{IgG} / \mathrm{IB} / \mathrm{S}$ & 35 & NI & $63^{\star}$ & 11 & $100 \ddagger$ & 48 & & & & & & 52 \\
\hline $\mathrm{IgG} / \mathrm{IB} / \mathrm{S}$ & 36 & NI & $76^{\star \star \star}$ & 5 & & & & & & & & 53 \\
\hline IgG/IB/S & 42 & NI & $59^{\star}$ & 7 & & & & & & & & 52 \\
\hline $\mathrm{IgG} / \mathrm{IB} / \mathrm{S}$ & 43 & NI & & & & & & $33^{\mathrm{b}}$ & 16 & $39^{\mathrm{b}}$ & 12 & 56 \\
\hline $\mathrm{IgG} / \mathrm{IB} / \mathrm{S}$ & 46 & NI & $54^{\star}$ & 14 & & & & & & & & 52 \\
\hline $\mathrm{IgG} / \mathrm{IB} / \mathrm{S}$ & 47 & NI & $82^{\star}$ & 45 & & & & & & & & 53 \\
\hline $\mathrm{IgG} / \mathrm{IB} / \mathrm{S}$ & 47 & NI & & & & & & $68^{\mathrm{b}}$ & 45 & $78^{\mathrm{b}}$ & 62 & 56 \\
\hline $\mathrm{IgG} / \mathrm{IB} / \mathrm{S}$ & 48 & NI & $34^{\star}$ & 7 & & & & & & & & 52 \\
\hline IgG/IB/S & 50 & NI & $82^{\star \star \star}$ & 30 & & & & & & & & 53 \\
\hline IgA/ESP/L & 51 & $\mathrm{Fl}$ & & & A:91 & & & & & A:91 & A: 0 & 55 \\
\hline IgA/ESP/L & 51 & $\mathrm{Fl}$ & & & C:78 & & & & & C: 100 & C:0 & 55 \\
\hline $\mathrm{IgG} / \mathrm{ESP} / \mathrm{L}$ & 51 & $\mathrm{Fl}$ & & & $\mathrm{A}: 44$ & & & & & A: 45 & A:0 & 55 \\
\hline $\mathrm{IgG} / \mathrm{ESP} / \mathrm{L}$ & 51 & $\mathrm{Fl}$ & & & $\mathrm{C}: 0$ & & & & & $\mathrm{C}: 33$ & $\mathrm{C}: 0$ & 55 \\
\hline $\mathrm{IgG} / \mathrm{IB} / \mathrm{S}$ & 51 & $\mathrm{Fl}$ & 78 & 14 & & & & & & & & 51 \\
\hline $\mathrm{IgG} / \mathrm{IB} / \mathrm{S}$ & 54 & NI & $83^{\star}$ & 18 & & & & & & & & 52 \\
\hline $\mathrm{IgG} / \mathrm{IB} / \mathrm{S}$ & 56 & NI & $85^{\star}$ & 50 & & & & & & & & 53 \\
\hline IgG/ELISA/S & 58 & HspB & 76 & 0 & & & & & & & & 50 \\
\hline $\mathrm{IgG} / \mathrm{IB} / \mathrm{S}$ & 59 & NI & & & & & & $73^{\star}$ & 45 & $100 \dagger$ & 50 & 56 \\
\hline $\mathrm{IgG} / \mathrm{IB} / \mathrm{S}$ & 60 & NI & $94^{\star \star}$ & 60 & & & & & & & & 53 \\
\hline All/IB/S & 60 & Hsp60 & & & $75^{\mathrm{c}}$ & $75^{\mathrm{c}}$ & & $75^{\mathrm{c}}$ & & 25 & 0 & 57 \\
\hline IgA/ELISA/S & 60 & Hsp60 & High $^{\mathrm{b}, \mathrm{d}}$ & Low & & & & & & & & 58 \\
\hline IgG/ELISA/S & 60 & Hsp60 & $\mathrm{High}^{\star \star \star d}$ & Low & & & & & & & & 58 \\
\hline $\mathrm{IgA} / \mathrm{IB} / \mathrm{L}$ & 61 & NI & & & $96^{\mathrm{b}}$ & 98 & & & & & & 26 \\
\hline $\mathrm{IgG} / \mathrm{IB} / \mathrm{S}$ & 62 & NI & & & & & & $38^{\mathrm{b}}$ & 41 & 658 & 25 & 56 \\
\hline $\mathrm{IgG} / \mathrm{IB} / \mathrm{S}$ & 66 & FSP & 94 & 16 & & & & & & & & 51 \\
\hline $\mathrm{IgG} / \mathrm{IB} / \mathrm{S}$ & 66 & NI & $46^{\star}$ & 16 & & & & & & & & 52 \\
\hline $\mathrm{IgG} / \mathrm{IB} / \mathrm{S}$ & 66 & NI & & & & & & $47^{\mathrm{b}}$ & 29 & $73+$ & 25 & 56 \\
\hline $\mathrm{IgG} / \mathrm{IB} / \mathrm{S}$ & 74 & NI & $34^{\star}$ & 11 & & & & & & & & 52 \\
\hline $\mathrm{IgG} / \mathrm{IB} / \mathrm{S}$ & 75 & NI & 75 & 0 & & & & & & & & 51 \\
\hline $\mathrm{IgG} / \mathrm{IB} / \mathrm{S}$ & 75 & NI & $85^{\star \star}$ & 40 & & & & & & & & 53 \\
\hline $\mathrm{IgG} / \mathrm{IB} / \mathrm{S}$ & 85 & NI & & & & & & $68^{\star}$ & 29 & 61 & 37 & 56 \\
\hline $\mathrm{IgG} / \mathrm{IB} / \mathrm{S}$ & 87 & NI & $61^{\star}$ & 19 & $83 \ddagger$ & 48 & & & & & & 52 \\
\hline IgA/ELISA/S & 87 & VacA & $\mathrm{High}^{\star \star \star d \mathrm{~d}}$ & Low & & & & & & & & 58 \\
\hline IgG/ELISA/S & 87 & VacA & $\mathrm{High}^{\star \star \star \star \mathrm{d}}$ & Low & & & & & & & & 58 \\
\hline $\mathrm{IgA} / \mathrm{IB} / \mathrm{L}$ & 90 & NI & & & $88^{\mathrm{b}}$ & 80 & & & & & & 26 \\
\hline $\mathrm{IgG} / \mathrm{IB} / \mathrm{S}$ & 90 & NI & 71 & 0 & & & & & & & & 51 \\
\hline $\mathrm{IgG} / \mathrm{IB} / \mathrm{S}$ & 120 & NI & 97 ฯ & 35 & & & & & & & & 53 \\
\hline $\mathrm{IgG} / \mathrm{IB} / \mathrm{S}$ & 120 & NI & & & & & & $55^{\mathrm{b}}$ & 33 & $69^{\mathrm{b}}$ & 50 & 56 \\
\hline $\operatorname{Ig} \mathrm{A} / \mathrm{IB} / \mathrm{L}$ & 120 & CagA & & & $100+t$ & 63 & & & & & & 26 \\
\hline $\mathrm{IgG} / \mathrm{IB} / \mathrm{S}$ & 120 & CagA & 86 & 0 & & & & & & & & 51 \\
\hline $\mathrm{IgG} / \mathrm{IB} / \mathrm{S}$ & 125 & $\mathrm{NI}$ & $71^{\star}$ & 19 & $83 \ddagger$ & 62 & & & & & & 52 \\
\hline IgG/IB/S & 128 & CagA & & & $\begin{array}{l}100+1+(\mathrm{DU}) \\
83^{\mathrm{b}}(\mathrm{GU})\end{array}$ & 60 & & & & 61 & 6 & 59 \\
\hline IgG/ELISA/S & 25 & CagA fr & & & $100^{c}$, 护 & $75^{\mathrm{c}}$ & & & & & & 60 \\
\hline IgG/ELISA/S & 25 & CagA fr & & & $59^{\mathrm{b}}$ & & & & & 44 & & 61 \\
\hline IgG/ELISA/S & 25 & CagA fr & & & & 66 & 0 & & & & & 62 \\
\hline IgG/ELISA/S & 25 & CagA fr & & & & & & 78 & 8 & 54 & 8 & 61 \\
\hline $\mathrm{IgG} / \mathrm{IB} / \mathrm{S}$ & 150 & NI & $85^{\mathrm{b}}$ & 70 & & & & & & & & 53 \\
\hline $\mathrm{IgG} / \mathrm{IB} / \mathrm{S}$ & 180 & NI & 68 & 0 & & & & & & & & 51 \\
\hline
\end{tabular}

${ }^{a}$ Where unnoted, no comparative statistics were performed. ${ }^{b}$ Not significantly different from corresponding $H$ pylori negative (Hp-) subjects. ${ }^{c} H$ pylori carrier status not determined. ${ }^{\mathrm{d}}$ Per cent responders not specified.

${ }^{\star} \mathrm{p}<0.05,{ }^{\star \star} \mathrm{p}<0.01,{ }^{\star \star \star} \mathrm{p}<0.001 v$ corresponding Hp- subjects.

$\mathrm{t} \mathrm{p}<0.05 v$ uninfected healthy individuals and infected cancer patients; $\ddagger \mathrm{p}<0.05 v$ patients with non-ulcer dyspepsia (NUD); $\mathrm{p}<0.05 v H$ pylori positive (Hp + ) patients with cancer, but no different from Hp- asymptomatic subjects; $\uparrow \mathrm{p}<0.0001 v \mathrm{Hp}-$ gastroscopy patients; $\dagger+\mathrm{p}<0.001 v$ infected patients with NUD; $+\dagger+\mathrm{p}<0.0001 v$ infected patients with NUD and asymptomatic individuals; $\ddagger \neq p<0.0005 v$ patients with NUD.

A, antrum; C corpus; DU, duodenal ulcer; ELISA, enzyme linked immunosorbent assay; ESP, ELISPOT; Fl, flagellin; fr, recombinant fragment; GU, gastric ulcer; IB, immunoblot; L, local; MW, molecular weight; NI, not identified; S, systemic; U, urease; U/A, urease A; U/B, urease B. 
and is also expressed at higher levels in infection in vivo. Gastric epithelial cells may be able to present bacterial antigens to $\mathrm{T}$ cells as during infection their endocyticendosomal system has been shown to contain $H$ pylori antigens and expression of the antigen processing enzyme cathepsin $\mathrm{E}$ is higher. ${ }^{5}$ Thus, gastric epithelial cells may be important antigen presenting cells (APCs) for CD4+ T cells in $H$ pylori infection. With regard to more conventional APCs, monocyte numbers are increased in the lamina propria in $H$ pylori infection ${ }^{5}$ and cathepsin $\mathrm{E}+$ macrophages are concentrated in the lamina propria immediately underlying the $H$ pylori colonised epithelium. HLA-DR is also upregulated on macrophages. ${ }^{5}$ In addition, gastric mucosal dendritic cell numbers are increased in infection relative to normal and uninfected dyspeptic gastric mucosae. ${ }^{5}$

Secreted products from $H$ pylori such as urease induce expression of HLA-DR and B7-2 on monocytes and gastric epithelial cells, ${ }^{18} 81{ }^{82}$ but interferon (IFN) $\gamma$ also has this effect. ${ }^{81}{ }^{82}$ Either $\mathrm{T}$ or natural killer cells can produce IFN- $\gamma$. Although natural killer cell numbers did not seem to be increased in H pylori infection in one report, ${ }^{83}$ another did show an increase. ${ }^{84}$

T CELLS IN H PYLORI ASSOCIATED INFLAMMATORY INFILTRATES HAVE A DISTINCTIVE PHENOTYPE AND ARE ACTIVATED

A number of studies have characterised the T cell component of the inflammatory infiltrate by immunohistochemical staining of gastric biopsy samples. The biopsy sample donors were always patients undergoing endoscopy for upper gastrointestinal complaints. As a consequence of this random recruitment, the donors tended to be heterogenous in their degree of gastritis and clinical picture. Comparisons of $H$ pylori positive gastric mucosae were made with histologically normal, uninfected and/or gastritic but uninfected mucosae. Sometimes these control groups were combined.

When compared with normal gastric mucosae, $H$ pylori positive samples had increased numbers of predominantly $\mathrm{CD} 3+\mathrm{CD} 4+$ and also some CD8+ $\mathrm{T}$ cells in the lamina propria in all ${ }^{78} 798385$ but one study, which found more $\mathrm{CD} 8+$ than CD4+ T cells. ${ }^{84}$ With regard to intraepithelial lymphocytes (IELs), although two of three reports suggested that they did not seem to increase in number, ${ }^{78} 8586$ an increased CD4:CD8 ratio was nevertheless also observed. ${ }^{78} 838586$ In the lamina propria, the increase in $\mathrm{CD} 4+$, but not $\mathrm{CD} 8+$, $\mathrm{T}$ cells correlated with increasing grades of gastritis, activity and density of bacterial colonisation $(r=0.87,0.92$ and 0.80 , respectively). ${ }^{86}$ This increase in the CD4:CD8 ratio did not occur in the gastric mucosal lamina propria of uninfected patients with dyspepsia of unspecified aetiology. ${ }^{78}$ To make the point that the gastric mucosa is capable of distinct immune responses, the chronic gastritides associated with pernicious anaemia and coeliac disease are characterised by distributions and phenotypes of $\mathrm{T}$ cells different from those in $H$ pylori positive gastric mucosae. Coeliac disease is characterised by a profound infiltration into the gastric epithelium of CD8+ cells with cytolytic potential. ${ }^{83}$ In contrast, gastritic mucosae of patients with pernicious anemia are characterised by infiltrates of $B$ cells and there is no alteration in the CD4:CD8 ratios, ${ }^{87} 88$ consistent with the concept that gastric mucosal damage in pernicious anemia is mediated primarily by humoral mechanisms.

The $\mathrm{T}$ cells infiltrating into both the lamina propria and the epithelium of infected gastric mucosae seemed to be mainly $\mathrm{T}$ cell receptor (TCR) $\alpha \beta+.{ }^{86}$ Two reports suggested that there was no absolute increase in TCR- $\gamma \delta+$ $\mathrm{T}$ cells in either compartment, ${ }^{86}{ }^{89}$ whereas a third found a significant increase in numbers relative to normal gastric mucosae in both compartments. ${ }^{78}$ This was also found in uninfected patients with gastritis, indicating it is not specific to $H$ pylori infection. TCR $-\gamma \delta+\mathrm{T}$ cells may therefore not play a significant role in $H$ pylori induced gastritis.

In infection, $\mathrm{T}$ cells from the lamina propria, but not the epithelium, ${ }^{90}$ were CD45RO+ and IL-2R $+{ }^{78} 85$ and thus have an activated/memory phenotype. Other activation markers are suggestive of some activation of IELs as there was a small but significant increase in cells expressing CD69 (an early $\mathrm{T}$ cell activation marker) as well as a significant decrease in leucocyte function associated antigen (LFA) 1 positive cells in $H$ pylori positive gastric mucosae relative to both normal and uninfected dyspeptic gastric mucosae..$^{90}$ A reduction in LFA-1 expression has been previously reported upon activation of intraepithelial T cells. ${ }^{91}$

T CELLS RESPOND BY PROLIFERATION AND IFN- $\gamma$ RELEASE TO $H$ PYLORI ANTIGENS

Several studies have analysed in vitro T cell responses to $H$ pylori antigens by infected and uninfected subjects. ${ }^{92-104}$ Nearly all studies recruited patients undergoing endoscopy for dyspepsia and divided them according to infection status. Occasionally healthy donors serologically positive for $H$ pylori infection were grouped with the dyspeptic patients, and thus the degree of gastritis and the clinical picture of the infected and uninfected groups were heterogenous.

Crude preparations of $H$ pylor $i$ induced proliferation and secretion of IFN- $\gamma$ and soluble IL-2R in vitro by both peripheral blood mononuclear cells (PBMC) and lamina propria lymphocytes (LPLs) of $H$ pylori infected donors. ${ }^{92-101}$ Whether IL-2 and IL-4 are secreted is not clear as in one study neither was induced ${ }^{93}$ whereas both were induced in another. ${ }^{100}$ Purified urease, Hsp60, and p25 also induce PBMC proliferation, ${ }^{98}{ }^{102}$ and Hsp60 stimulates IL-10 but not IFN- $\gamma$ release by PBMC from infected subjects. ${ }^{102}$ Proliferation in response to $H$ pylori antigens, at least in PBMC, was due mainly to CD4+ T cells. ${ }^{93}$ The response was not caused by $H$ pylori superantigens or mitogens ${ }^{95} 9698$ and multiple HLA-DR molecules seemed to be involved in $\mathrm{T}$ cell recognition. ${ }^{94}$ The cloning efficiency of $H$ pylori specific mucosal $\mathrm{T}$ cells compared with their precursor frequency in the blood suggests that these cells accumulate in gastric tissue. ${ }^{103}$

Surprisingly, there seem to be very few differences in the quality of $\mathrm{T}$ cell responses to $H$ pylori by uninfected compared with $H$ pylori positive subjects in all criteria assessed so far. ${ }^{92-101}$ Responsiveness to $H$ pylori by uninfected donors resembles an analogous situation in malaria, where $\mathrm{T}$ cells from blood donors who have never lived in or visited malarious countries vigorously respond by proliferation and production of IFN- $\gamma$ to malaria antigens. ${ }^{105-107} \mathrm{~T}$ cell clones reactive to malaria proteins were also able to respond to crude extracts of many common microorganisms, ${ }^{107} 108$ and it is thus possible that the uninfected donor response to $H$ pylori reflects prior encounter with microorganisms with common $\mathrm{T}$ cell determinants. Unlike malaria, however, there is a paradoxical quantitative difference between $H$ pylori infected and uninfected subjects in that PBMC and lamina propria cells from $H$ pylori positive individuals showed a statistically significant reduced proliferative response and lower IFN- $\gamma$ release. ${ }^{92-101}$ The reduced response seemed to occur on challenge with the cytoplasmic fraction and urease but not the membrane fraction of $H$ pylori. ${ }^{96}$ Thus $H$ pylori may induce immune responses which downregulate proliferation and IFN- $\gamma$ secretion. Notably, the only difference between infected and uninfected donors in their in vitro $\mathrm{T}$ 
cell responses to $H$ pylori detected to date was a small but significant increase in the population of IL-2R+CD8+ cells in $H$ pylori positive donor PBMC along with a significant increase in soluble CD8 release. ${ }^{93}$ The CD8+ T cell response may reflect the induction of specific responses which do not occur in uninfected individuals and that could regulate IFN $-\gamma$ secretion and proliferation by either regulatory cytokines or anti-idiotypic mechanisms.

As the studies reporting this phenomenon investigated dyspeptic patients only, it is not known whether the reduced immune response to infection also occurs in asymptomatic donors. The fact that there are pre-existing $\mathrm{T}$ cell responses to $H$ pylori should not be ignored. It is possible that such responses could skew reactivity to the bacterium at the initial encounter in such a way that an adequate defence cannot be mounted, as has been postulated for malaria ${ }^{105}$ and viruses. ${ }^{109}$ Redirecting the immune response, possibly towards epitopes unique to $H$ pylori, could be an important consideration in vaccine design.

Although $H$ pylori infection clearly elicits a $\mathrm{T}$ cell response, there is no evidence that it is protective. This may, however, reflect the fact that infected but asymptomatic donors, or donors who may have had transient infections which they were apparently able to resolve, have never been examined. The assessment of mucosal $\mathrm{T}$ cell responses by such donors would be highly informative.

ROLE OF T CELLS IN GASTRODUODENAL PATHOLOGY AND THE TH1/TH2 PARADIGM

Much more evidence exists suggesting that $\mathrm{T}$ cells are involved in the induction of gastroduodenal pathology. Ulcerogenesis may be mediated by $\mathrm{T}$ cells, since, as estimated by FACS, patients with peptic ulcer have a significantly higher proportion of IL-2R+CD4+ gastric mucosal $\mathrm{T}$ cells than patients with NUD. ${ }^{110}$ Furthermore, the development of MALT lymphomas seems to be dependent on the presence of $H$ pylori specific $\mathrm{T}$ cells, as shown by the fact that tumour cells from such lymphomas proliferate in the presence of non-neoplastic tumour infiltrating CD4+CD45RO+ T cells ${ }^{111}$ and $H$ pylori, but not of $H$ pylori alone. ${ }^{12} 113$ The activation and proliferation of the neoplastic B cells in low grade lymphomas depends on CD40, which interacts with its counterpart CD40L on $\mathrm{T}$ cells to induce B cell maturation. The role of T cells in high grade lymphomas is less clear as tumour cell proliferation in these lymphomas is supported by CD40 binding in one report ${ }^{114}$ and independent of tumour infiltrating $\mathrm{T}$ cells in another. ${ }^{112}$ A proportion (7-24\%) of the tumour infiltrating $\mathrm{T}$ cells in low grade lymphomas express CD40L. ${ }^{11}$ One study also showed that low grade tumour cell proliferation is assisted by IL- 4 and IL-10, but not IFN- $\gamma$ and IL-2, whereas high grade lymphomas are assisted by all four cytokines. ${ }^{114}$ Thus, $\mathrm{T}$ cells specific for $H$ pylori and secreting IL-4 and IL-10 may be responsible for the initiation and perhaps progression of MALT lymphomas.

CD4+ T helper (Th) cells can be functionally polarised into either IFN- $\gamma$ secretors (Th1) or IL-4, IL-5, IL-10, and IL-13 secretors (Th2), ${ }^{115} 116$ with $\mathrm{T}$ cells expressing cytokines of both patterns being termed Th0 T cells. Th1 and Th2 cells reciprocally inhibit each other, and there is widespread speculation that $H$ pylori predominantly induces a Th1 response which is normally kept in check by moderate Th2 responses. ${ }^{104}$ It is believed that disease occurs upon dysregulation of the inhibitory Th2 responses, causing overproduction of IFN- $\gamma$ which results in increased activation of macrophages, neutrophils and eosinophils. These effector cells may then damage epithelial integrity by release of oxygen radicals, nitric oxide, proteolytic enzymes, and induction of apoptosis. ${ }^{10} 18$ 117-120
This hypothesis is important for vaccine development because it implies that a vaccine which upregulates Th2 responses may be protective. However, as we will show, the evidence supporting the hypothesis is weak or circumstantial and open to alternative interpretations. There are three lines of evidence: firstly, IFN- $\gamma$ and IL-12 (Th1 cytokines), but not IL-4 (a classic Th2 cytokine) are thought to be present in the gastric mucosae of $H$ pylori infected dyspeptic patients. Secondly, LPLs from $H$ pylori positive patients do not bear CD $30,{ }^{85}$ which is a putative marker for Th2 cells. ${ }^{115}$ Thirdly, the presence of ulcers has been reported to be associated with IFN- $\gamma$ secreting CagA specific Th1 cells. ${ }^{103}{ }^{104}$ Each of these points will be addressed in turn.

\section{Th1 and Th2 cytokines in biopsy material}

Table 2 summarises the studies investigating the presence of Th1 and Th2 cytokines in biopsy material. ${ }^{84} 85103$ 121-128 Cytokines tested only once are not shown. Comparisons of $H$ pylori positive biopsy samples were usually made with normal gastric mucosae and occasionally also with gastritic mucosae from uninfected dyspeptic patients. With the exception of two studies with defined patient groups, ${ }^{103} 127$ gastritic groups combined dyspeptic patients with a wide spectrum of gastritis severity and disease. A number of methodologies were used and more attention is focused here on studies quantifying cytokine protein production than on studies measuring cytokine mRNA.

The classic Th1 cytokines are IFN- $\gamma$ and IL-12. Most biopsy specimens from $H$ pylori positive patients had high numbers of IFN- $\gamma+\mathrm{T}$ cells ${ }^{85} 122126$ and the frequencies of IFN- $\gamma$ secreting T cells were significantly higher in infected than in normal gastric mucosae. ${ }^{124}{ }^{127}$ However, samples from uninfected dyspeptic patients had many more IFN- $\gamma$ secreting cells than the infected samples, ${ }^{124}$ suggesting that the apparent increase in IFN- $\gamma$ during infection is not pathologically significant. Supporting this is the observation that there was no difference in numbers of IFN- $\gamma+$ cells in samples from infected peptic ulcer and asymptomatic donors. ${ }^{127}$ The case for IL-12 is not clear because although infected samples were more frequently positive for IL-12 mRNA than those from normal and uninfected dyspeptic donors, ${ }^{103} 122125$ a single report measuring IL-12 protein in biopsy material found similar amounts in both $H$ pylori positive gastric mucosae and normal gastric mucosae. ${ }^{122}$

Another marker of a Th1 phenotype is IL-2, an autocrine growth factor for $\mathrm{T}$ cells produced both by Th1 and Th2 cells but more abundantly by Th1 cells. ${ }^{115}$ Infected gastric mucosae had high numbers of IL-2+ LPL ${ }^{85}$ biopsy specimens secreted the cytokine in culture ${ }^{84}$ and half of the specimens were positive for IL-2 mRNA in one study. ${ }^{121}$ In the latter study, uninfected gastritic biopsy specimens were significantly less frequently positive for IL-2 mRNA than infected samples but examination by ELISA showed that both produced equivalent amounts of IL-2. ${ }^{84}$ mRNA of another Th1 cytokine, IFN- $\alpha$, which induces Th1 responses, ${ }^{129}$ was present at equivalent frequencies in $H$ pylori positive and uninfected gastritic mucosae and normal gastric mucosae (about $64 \%$ ). ${ }^{123}$

IL-4 is the classic Th2 cytokine. It is an autocrine Th2 growth factor ${ }^{115}$ which promotes Th2 cell development. Five studies found no or very low levels of IL-4 mRNA or IL-4+ cells in gastric mucosae of normal, infected, or uninfected dyspeptic donors. ${ }^{85} 103122123126$ Immunohistochemical, ELISPOT and biopsy ELISA studies did detect IL-4 production but no significant quantitative differences between infected and normal or uninfected dyspeptic donors were found. ${ }^{84} 124127$

IL-10 is produced in higher quantities by Th2 cells and it suppresses Th1 cells. ${ }^{116}$ It is also produced by cells other 
Table 2 Review of cytokine analysis of gastric mucosal biopsy specimens of Helicobacter pylori infected and uninfected gastritic and histologically normal patients

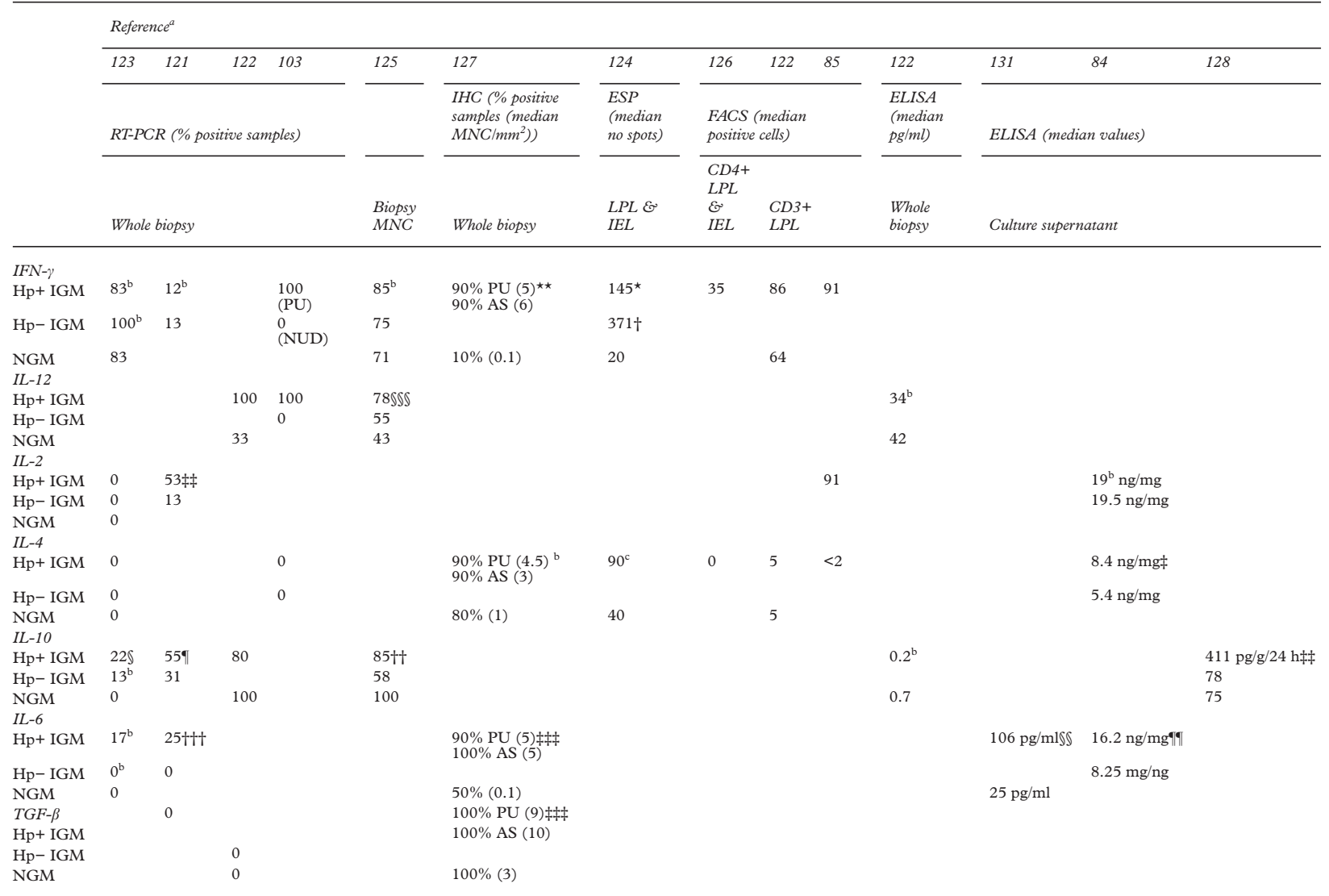

*Significantly different from $H$ pylori negative $(\mathrm{Hp}-)$ inflamed gastric mucosae (IGM) $(\mathrm{p}<0.05)$ and normal gastric mucosae $(\mathrm{NGM})(\mathrm{p}<0.05) .{ }^{\star \star} \mathrm{Peptic}$ ulcer $(\mathrm{PU})$ and asymptomatic $(\mathrm{AS})$ combined significantly different from NGM ( $<<0.01$ ) but not each other. †Significantly different from NGM $(\mathrm{p}<0.01)$. $¥$ Significantly different from Hp- IGM ( $\mathrm{p}=0.01)$. \Significantly different from uninfected IGM $(\mathrm{p}=0.06)$. $\uparrow$ Trend towards significant difference from uninfected IGM $(\mathrm{p}=0.11)$. H†Trend towards significant difference from uninfected IGM ( $\mathrm{p}=0.08)$. $\neq \neq$ Significantly different from NGM $(p<0.01)$ and Hp- IGM $(p<0.05)$. †t†Significantly different from Hp-IGM ( $\mathrm{p}=0.06)$.

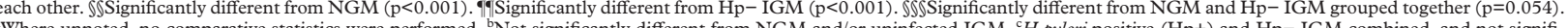
a Where unnoted, no comparative statistics were performed. ${ }^{b}$ Not significantly different from NGM and/or uninfected IGM. ${ }^{\circ} H$ pylori positive (Hp+) and Hp- IGM combined, and not signifi-
cantly different from NGM. antly different from NGM

FN, interferon; TGF, transforming growth factor; RT-PCR, reverse transcription polymerase chain reaction; IEL, intraepithelial lymphocytes; IHC; immunohistochemistry; LPL, lamina propria lymphocytes; ESP, ELISPOT; ELISA, enzyme linked immunosorbent assay; MNC, mononuclear cells.

than T cells. Biopsy material from infected donors secreted significantly more IL-10 than that from normal or uninfected dyspeptic donors, ${ }^{128}$ and a significant correlation between IL-10 secretion and the chronic inflammation score $(r=0.4)$ was found. ${ }^{128}$ Notably, measurements of IL-10 mRNA repeatedly indicated that gastritic mucosae from uninfected samples were significantly less frequently positive than infected samples $\left(\mathrm{p}=0.11,{ }^{121} 0.06,{ }^{123} 0.08,{ }^{125}\right.$ and $0.05^{128}$ ).

Like IL-10, IL-6 is produced in greater amounts by Th2 cells $^{116130}$ and also by non-T cells. Biopsy samples from infected donors secreted significantly more IL-6 in culture than samples from either normal ${ }^{131}$ or uninfected dyspeptic donors. ${ }^{84}$ Furthermore, $H$ pylori positive gastric mucosae had significantly more IL-6+ cells than normal samples. ${ }^{127}$ In the latter study, however, no difference between infected asymptomatic and peptic ulcer donors was found, suggesting that IL-6 may not play a role in ulcerogenesis.

Transforming growth factor (TGF) $\beta$ may polarise the $T$ cell response towards a Th2 response. ${ }^{132}$ There were significantly more TGF- $\beta+$ cells in gastric mucosae from infected than from normal donors, although again there was no difference between infected peptic ulcer and asymptomatic donors. ${ }^{127}$

Thus, relative to normal controls, IFN- $\gamma$, IL-2, IL-10, IL-6, and TGF- $\beta$ seem to be significantly upregulated in $H$ pylori positive dyspeptic gastritis, whereas uninfected gastritic patients showed an increase in IFN- $\gamma$, IL- 2 and possibly IL-6 but not IL-10. There were quantitative differences between infected and uninfected gastritic mucosae in that less IFN- $\gamma$ and more IL-10 and IL- 6 were produced in infection.

With regard to the Th1/Th2 paradigm, although the upregulation of IFN- $\gamma$ in infection supports the hypothesis, the crucial comparison between infected asymptomatic and peptic ulcer subjects indicates that the apparent increase in IFN- $\gamma$ is not pathologically significant, at least for ulcerogenesis. ${ }^{127}$ In support, an association between the frequency of IFN- $\gamma$ expressing cells and the presence of ulcers was not found. ${ }^{124}$ Furthermore, although IL-4 is not produced, there is evidence of Th2 activity in dyspepsia associated with infection. IL-10, a major regulatory Th2 cytokine, seems to be upregulated in infected gastric mucosae of dyspeptic patients, and its expression correlates with disease activity. Indeed, as uninfected dyspeptic patients produced IFN- $\gamma$ but not IL-10 whereas infected subjects produced both, the presence of IL-10 (but not IFN- $\gamma$ ) may be specific to gastritis induced by $H$ pylori and suggests that IL-10 is not just produced in an attempt by the host's immune system to control IFN- $\gamma$ production. The Th 2 cytokines IL- 6 and TGF- $\beta$ are also upregulated in infected patients, although they did not correlate with disease parameters. IL-13, which mimics IL-4 in many functions, has not been investigated. There is also indirect evidence of Th2 activity in the gastric mucosa in that most infected dyspeptic patients have, in their plasma, $H$ pylori 
specific IgE, ${ }^{38}$ whose production is dependent on IL- $4,{ }^{115}$ and MALT lymphomas seem to be initiated by Th2 T cells $^{114}$ (see earlier). Thus, the measurement of cytokines in biopsy material does not at this point provide evidence of a pathogenic IFN- $\gamma$ dependent Th 1 response.

Presence of CD30, a Th2 marker, on gastric T cells The second line of evidence supporting the hypothesis is that CD30, a possible Th2 marker, does not occur on LPL from infected patients. ${ }^{85}$ However, lamina propria cells from uninfected gastritic patients also did not express this molecule. ${ }^{85}$ In addition, there is some controversy as to whether CD30 really does discriminate between Th1 and Th2 cells. ${ }^{133}$

\section{Th1 clones in infected gastric mucosa}

Mucosal $\mathrm{T}$ cell clones have been generated from biopsy material from $H$ pylori positive patients with peptic ulcer. ${ }^{94} 103104$ The clones generated were all CD4+TCR$\alpha \beta+$ and proliferated in response to crude extracts of $H$ pylori, CagA, VacA, urease, or Hsp60. ${ }^{94} 103$ Analysis of the cytokine release by $H$ pylori specific mucosal clones showed that most secreted IFN- $\gamma$ but not IL-4 nor IL- $5^{103}$ whereas the remainder were of the Th0 phenotype. It was thus suggested that the $\mathrm{T}$ cell response to $H$ pylori in patients with peptic ulcer predominantly follows a Th 1 profile. It should be noted, however, that the clones were generated with IL-2, which is known particularly to support Th1 cell growth. ${ }^{134}$ In a subsequent study, however, it was found that infected patients with peptic ulcers had significantly more Th1 clones than infected patients with NUD, ${ }^{104}$ and that these recognised CagA more frequently, whereas most of the Th0 clones from both sets of patients responded to either VacA, urease or Hsp. ${ }^{103} 104$

Although these studies provide the most direct evidence of the role of Th1 cells in $H$ pylori induced pathogenesis, it should be noted that the Th1 clones were defined on the basis of a lack of IL- 4 and IL- 5 production, and other Th2 cytokines (e.g., IL-10, IL-13) were not examined. Furthermore, it was not indicated in the study whether all six patients with peptic ulcer had clones reacting to CagA, or whether the CagA specific clones were derived from just one or two patients. If the latter was the case, this would clearly make the study unrepresentative.

The remaining evidence for the hypothesis is that studies in animal models have shown that immunisation with $H$ pylori antigens can provide Th2 mediated protection against $H$ pylori colonisation. ${ }^{135}$ Another study, however, showed that induction of a fine balance between both Th1 and $\mathrm{Th} 2$ responses was necessary for protection. ${ }^{136}$ In any case, there are doubts that the mouse system adequately models the human situation, ${ }^{35}$ which is probably one reflecting millenia of co-evolution. Thus, whether an imbalance in Th1/Th2 responses really is responsible for $H$ pylori associated gastroduodenal pathology in humans requires more investigation. Indeed, the cytokine analyses of biopsy material question whether the inflammation induced by $H$ pylori infection is Th1 type in the first place, and more importantly, it indicates that IFN- $\gamma$ does not play a central role, at least in ulcerogenesis. The simplistic distinction between pathogenic IFN- $\gamma$ producing Th1 and protective IL- 4 producing Th 2 cells may not be pertinent in this infection.

CYTOLYTIC T CELLS MAY CONTRIBUTE TO EPITHELIAL DESTRUCTION

Of the classic Th1/Th2 cytokines discussed earlier, the only one correlating with disease parameters was IL-10. ${ }^{128}$ In addition, IL-7, whose mRNA was found more frequently in infected (83\%) than in either uninfected dys- peptic $(33 \%)$ or normal gastric mucosae $(38 \%)(p<0.05)$, has been shown to correlate significantly with disease severity $(p<0.05) .{ }^{123}$ IL-7 is a pleiotropic cytokine (not produced by $\mathrm{T}$ cells) which stimulates the proliferation and differentiation of mature CD4+ and CD8+ T cells. Its role in modulating Th1 and Th2 function is undetermined; in some systems IFN- $\gamma$ release is enhanced by addition of IL-7, ${ }^{137}{ }^{138}$ whereas in others it is reduced ${ }^{139}$ or unchanged ${ }^{140}$ with or without a concomitant change in IL-4 production. ${ }^{137} 139{ }^{140}$ Its role in augmenting cytotoxic $\mathrm{T}$ cell (CTL) cytotoxicity is, however, quite well established, ${ }^{137138140141}$ and it is possible that it may be responsible for the increased cytolytic character of the $\mathrm{T}$ cells found in $H$ pylori infected stomachs as shown by a statistically significant increase in granzyme $\mathrm{B}+\mathrm{T}$ cells in both the lamina propria and epithelium of infected dyspeptic patients. ${ }^{83} \mathrm{CTL}$ lysis of the epithelium could thus contribute to the epithelial erosions associated with infection. This is supported by the observed increase in infection of gastric mucosal intraepithelial $\mathrm{T}$ cells in patients with ${ }^{14}$ compared with those without ulcers, ${ }^{78} 81$ indicating that the cytolytic cells may be in direct contact with epithelial cells.

\section{Concluding comments}

Increasing interest has been shown in the possibility of developing a vaccine against $H$ pylori. Two types of vaccines are potentially possible: a prophylactic vaccine, which prevents new infections, and a therapeutic vaccine, which eliminates an existing infection. Current antibiotic eradication of $H$ pylori infection is reliable but costly and there is the danger of increasing antibiotic resistance in bacterial strains. ${ }^{142}$ A cheap and potent therapeutic vaccine which eradicates infection and associated disease and simultaneously secures long lasting immunity is thus highly desirable.

Regarding prophylactic vaccines, which would allow global eradication of $H$ pylori, some caution may need to be exercised. The vast majority of $H$ pylori infected individuals never develop disease symptoms ${ }^{9}$ and colonisation with $H$ pylori might even be beneficial for the human host ${ }^{143}$ as recent studies have suggested that $H$ pylori infection may protect against reflux oesophagitis ${ }^{143-145}$ and that colonisation by CagA positive strains may reduce the risk of developing cancer of the oesophagus and gastric cardia. ${ }^{146}$ Thus, eradicating $H$ pylori might reduce the risk of developing peptic ulcers, MALT lymphomas and cancers of the distal stomach while increasing the risk of developing reflux oesophagitis and cancers of the oesophagus and proximal stomach. These observations require thorough confirmation in large scale longitudinal studies.

This review shows that strong antibody and $\mathrm{T}$ cell responses are elicited by $H$ pylori. That these responses apparently cannot, however, clear the infection probably reflects the plethora of immune escape mechanisms which the bacterium has evolved so as to thrive in its host. Understanding the nature of these mechanisms and also how a normally benign coexistence can result in pathology might lead to rational approaches to vaccine design. As most studies to date have examined infected donors with signs of $H$ pylori associated pathology, attention has thus focused on how $\mathrm{T}$ cells and antibodies could induce this pathology. It may be argued that inducing immune responses which oppose pathological $\mathrm{T}$ and $\mathrm{B}$ cell activity should be a major goal of vaccination as such responses could modulate disease and possibly also result in the elimination of the bacterium. The popular hypothesis that a vaccine should induce Th2 immunity which suppresses pathological Th1 responses is in line with this goal. This review has shown, however, that the basis of this hypothesis 
can be questioned and should be investigated more thoroughly. Furthermore, immune deviation is not the only $\mathrm{T}$ cell regulatory mechanism, and the possibility that-for example, a defect in the anti-idiotypic network contributes to pathology should be investigated. The role of cytotoxic CD8+ $\mathrm{T}$ cells in pathology, in particular ulcerogenesis, should also be assessed further.

It is possible that the different pathologies associated with $H$ pylori infection could be promoted by quite different mechanisms, and thus a vaccine opposing ulcerogenic immunity may be ineffective (or even pathogenic) in an immune context which leads to atrophy or MALT lymphoma. Other diseases not yet unequivocally associated with $H$ pylori infection, such as autoimmune gastritis, ${ }^{49}$ may also be triggered by this bacterium by quite distinct mechanisms. Thus, it is essential that clearly defined patient groups are studied. In addition, infected but asymptomatic donors should be investigated to allow an understanding of the immune mechanisms permitting an apparently harmonious coexistence between host and bacterium.

We have also highlighted several candidate vaccine antigens, including urease, flagellin, flagellar sheath protein, Hsp60, CagA and the unidentified antigens p19, p25 and p35 which are recognised frequently by antibodies from infected subjects. Several antigens are recognised more frequently by subjects with $H$ pylori associated disease, namely CagA, p35 and p87/VacA. All of these antigens may be important candidate vaccine antigens.

Y ZEVERING

L JACOB

T F MEYER

Max-Planck-Institut für Infektionsbiologie,

Monbijoustrasse 2,

10117 Berlin,

Germany

Correspondence to: Dr Yinka Zevering, Het Nederlands Kanker Instituut, Plesmanlaan 121, 1066 CX Amsterdam, The Netherlands.

1 Wyle FA, Tarnawski A, Schulman D, et al. Evidence for gastric mucosal cell nvasion by C. pylori: an ultrastructural study. 7 Clin Gastroentero 1990;12:S92-8.

2 Marshall BJ. Helicobacter pylori. Am f Gastroenterol 1994;89:S116-28.

3 Stolte M, Eidt S. Helicobacter pylori and the evolution of gastritis. Scand $\mathcal{F}$ Gastroenterol 1996;(suppl 214):13-16.

4 Robert ME, Weinstein WM. Helicobacter pylori-associated gastric pathology. Gastroenterol Clin North Am 1993;22:59-72.

5 Fiocca R, Luinetti O, Villani L, et al. Epithelial cytotoxicity, immune responses, and inflammatory components of Helicobacter pylori gastritis. Scand F Gastroenterol 1994;(suppl 205):11-21.

6 Wyatt JI, Rathbone BJ, Heatley RV. Local immune response to gastric Campylobacter in non-ulcer dyspepsia. F Clin Pathol 1986;39:863-70.

7 Parsonnet J, Hansen S, Rodriguez L, et al. Helicobacter pylori infection and gastric lymphoma. $N$ Engl F Med 1994;330:1267-71.

8 Wotherspoon AC, Doglioni C, Diss TC, et al. Regression of primary low-grade B-cell gastric lymphoma of mucosa-associated lymphoid tissue type after eradication of Helicobacter pylori. Lancet 1993;342:575-7.

9 Telford JL, Covacci A, Rappuoli R, et al. Immunobiology of Helicobacter pylori infection. Curr Opin Immunol 1997;9:498-503.

10 McGovern TW, Talley NJ, Kephart GM, et al. Eosinophil infiltration and degranulation in Helicobacter pylori-associated chronic gastritis. Dig Dis Sci 1991;36:435-40.

11 Karttunen T, Niemela S, Lehtola J. Helicobacter pylori in dyspeptic patients: quantitative association with severity of gastritis, intragastric $\mathrm{pH}$, and serum gastrin concentration. Scand 7 Gastroenterol 1991; (suppl 186): $124-34$.

12 Niemela S, Karttunen T, Kerola T, et al. Ten year follow up study of ymphocytic gastritis: further evidence on Helicobacter pylori as a cause of lymphocytic gastritis and corpus gastritis. F Clin Pathol 1995;48:1111-16.

13 Flejou JF, Bahame P, Smith AC, et al. Pernicious anaemia and Campylobacter like organisms; is the gastric antrum resistant to colonisation? Gut 1989;30:60-4.

14 Steer HW. The gastro-duodenal epithelium in peptic ulceration. 7 Pathol 1985;146:355-62.

15 Terres AM, Pajares JM. An increased number of follicles containing activated $\mathrm{CD} 69^{+}$helper $\mathrm{T}$ cells and proliferating $\mathrm{CD} 71^{+} \mathrm{B}$ cells are found in H. pylori-infected gastric mucosa. Am f Gastroenterol 1998;93:579-83.

16 Stolte M, Eidt S. Lymphoid follicles in antral mucosa: immune response to Campylobacter pylori? f Clin Pathol 1989;42:1269-71.

17 Isaacson PG, Spencer J. Malignant lymphoma of mucosa-associated lymphoid tissue. Histopathology 1987;11:445-62.

18 Mai UE, Perez-Perez GI, Wahl LM, et al. Soluble surface proteins from Helicobacter pylori activate monocytes/macrophages by lipopolysaccharide-independent mechanism. F Clin Invest 1991;87:894-900.
19 Mai UE, Perez-Perez GI, Allen JB, et al. Surface proteins from Helicobacter pylori exhibit chemotactic activity for human leukocytes and are present in gastric mucosa. $\mathcal{F}$ Exp Med 1992;175:517-25.

20 Huang J, O'Toole PW, Doig P, et al. Stimulation of interleukin-8 production in epithelial cell lines by Helicobacter pylori. Infect Immun 1995;63:1732-

21 Sharma SA, Tummuru MK, Miller GG, et al. Interleukin-8 response of gastric epithelial cell lines to Helicobacter pylori stimulation in vitro. Infect Immun 1995;63:1681-7.

22 Nielsen H, Andersen LP. Chemotactic activity of Helicobacter pylori sonicate for human polymorphonuclear leucocytes and monocytes. Gut 1992;33:738-42.

23 Nielsen H, Andersen LP. Activation of human phagocyte oxidative metabolism by Helicobacter pylori. Gastroenterology 1992;103:1747-53.

24 Blaser MJ. Hypotheses on the pathogenesis and natural history of Helicobacter pylori-induced inflammation. Gastroenterology 1992;102:720

25 Blaser MJ. Helicobacter pylori: microbiology of a 'slow' bacterial infection. Trends Microbiol 1993; 7:255-60.

26 Crabtree JE, Taylor JD, Wyatt JI, et al. Mucosal IgA recognition of Helicobacter pylori $120 \mathrm{kDa}$ protein, peptic ulceration, and gastric pathology. Lancet 1991 10;338:332-5.

27 Crabtree JE, Shallcross TM, Wyatt JI, et al. Mucosal humoral immune response to Helicobacter pylori in patients with duodenitis. Dig Dis Sci 1991;36:1266-73.

28 Wyatt JI, Rathbone BJ. Immune response of the gastric mucosa to Campylobacter pylori. Scand F Gastroenterol 1988;(suppl 142):44-9.

29 Mollenkopf C, Steininger H, Weineck G, et al. Gastritis: immunohistochemical detection of specific and nonspecific immune response to Helicobacter pylori. $Z$ Gastroenterol 1990;28:327-34.

30 Luzza F, Maletta $M$, Imeneo $M$, et al. Salivary-specific immunoglobulin G in the diagnosis of Helicobacter pylori infection in dyspeptic patients. Am $\mathcal{F}$ Gastroenterol 1995;90:1820-3.

31 Kosunen TU, Seppala K, Sarna S, et al. Diagnostic value of decreasing IgG, $\mathrm{IgA}$, and IgM antibody titres after eradication of Helicobacter pylori. Lancet $1992 \cdot 339 \cdot 893-5$.

32 Hirschl AM, Brandstatter G, Dragosics B, et al. Kinetics of specific IgG antibodies for monitoring the effect of anti-Helicobacter pylori chemotherapy. F Infect Dis 1993;168:763-6.

33 Bontkes HJ, Veenendaal RA, Pena AS, et al. IgG subclass response to Helicobacter pylori in patients with chronic active gastritis and duodenal ulcer. Scand F Gastroenterol 1992;27:129-33.

34 Aceti A, Celestino D, Caferro $\mathrm{M}$, et al. Basophil-bound and serum immunoglobulin $\mathrm{E}$ directed against Helicobacter pylori in patients with chronic gastritis. Gastroenterology 1991;101:131-7.

35 Kleanthous H, Lee CK, Monath TP. Vaccine development against infection with Helicobacter pylori. Br Med Bull 1998;54:229-41.

36 Thomas JE, Austin S, Dale A, et al. Protection by human milk IgA against Helicobacter pylori infection in infancy. Lancet 1993;342:121

37 Watanabe T, Goto H, Arisawa T, et al. Relationship between local immune response to Helicobacter pylori and the diversity of disease: investigation of H. pylori-specific IgA in gastric juice. $\mathcal{F}$ Gastroenterol Hepatol 1997;12:6605

38 Bogstedt AK, Nava S, Wadstrom T, et al. Helicobacter pylori infections in IgA deficiency: lack of role for the secretory immune system. Clin Exp Immunol 1996;105:202-4.

39 Schaffer FM, Monteiro RC, Volanakis JE, et al. IgA deficiency. Immunodefic Rev 1991;3:15-44.

40 Tosi MF, Czinn SJ. Opsonic activity of specific human IgG against Helicobacter pylori. F Infect Dis 1990;162:156-62.

41 Cover TL, Cao P, Murthy UK, et al. Serum neutralizing antibody response to the vacuolating cytotoxin of Helicobacter pylori. 7 Clin Invest 1992;90:913-18.

42 Sugiyama T, Awakawa T, Hayashi S, et al. The effect of the immune response to Helicobacter pylori in the development of intestinal metaplasia. Eur 7 Gastroenterol Hepatol 1994;6:S89-92.

43 Negrini R, Lisato L, Zanella I, et al. Helicobacter pylori infection induces antibodies cross-reacting with human gastric mucosa. Gastroenterology 1991;101:437-45.

44 Negrini R, Savio A, Poiesi C, et al. Antigenic mimicry between Helicobacter pylori and gastric mucosa in the pathogenesis of body atrophic gastritis. Gastroenterology 1996;111:655-65.

45 Appelmelk BJ, Negrini R, Moran AP, et al. Molecular mimicry between Helicobacter pylori and the host. Trends Microbiol 1997;5:70-3.

46 Appelmelk BJ, Simoons-Smit I, Negrini R, et al. Potential role of molecular mimicry between Helicobacter pylori lipopolysaccharide and host Lewis blood group antigens in autoimmunity. Infect Immun 1996;64:2031-40.

47 Wirth HP, Yang M, Peek RM Jr, et al. Helicobacter pylori Lewis expression is related to the host Lewis phenotype. Gastroenterology 1997;113:1091-8.

48 Appelmelk BJ, Faller G, Claeys D, et al. Bugs on trial: the case of Helicobacter pylori and autoimmunity. Immunol Today 1998;19:296-9.

49 Desai HG, Amarapurkar DN. New look at chronic gastritis. F Clin Gastroenterol 1992;14:278-80.

50 Suerbaum S, Thiberge JM, Kansau I, et al. Helicobacter pylori HspA-HspB heat-shock gene cluster: nucleotide sequence, expression, putative function and immunogenicity. Mol Microbiol 1994;14:959-74.

51 Faulde M, Cremer J, Zoller L. Humoral immune response against Helicobacter pylori as determined by immunoblot. Electrophoresis 1993;14: 945-51.

52 Aucher P, Petit ML, Mannant PR, et al. Use of immunoblot assay to define serum antibody patterns associated with Helicobacter pylori infection and with H. pylori-related ulcers. F Clin Microbiol 1998;36:931-6.

53 Andersen LP, Espersen F. Immunoglobulin G antibodies to Helicobacter pylori in patients with dyspeptic symptoms investigated by the western immunoblot technique. f Clin Microbiol 1992;30:1743-51.

54 Drouet EB, Denoyel GA, Boude M, et al. Characterization of an immunoreactive species-specific 19-kilodalton outer membrane protein from Helicobacter pylori by using a monoclonal antibody. F Clin Microbiol 1991;29:1620-4

55 Mattsson A, Quiding-Jarbrink M, Lonroth $\mathrm{H}$, et al. Antibody-secreting cells in the stomachs of symptomatic and asymptomatic Helicobacter pyloriinfected subjects. Infect Immun 1998;66:2705-12. 
56 Klaamas $\mathrm{K}$, Held $\mathrm{M}$, Wadstrom $\mathrm{T}$, et al. IgG immune response to Helicobacter pylori antigens in patients with gastric cancer as defined by ELISA and immunoblotting. Int $\mathcal{F}$ Cancer 1996;67:1-5.

57 Macchia G, Massone A, Burroni D, et al. The Hsp60 protein of Helicobacter pylori: structure and immune response in patients with gastroduodenal diseases. Mol Microbiol 1993;9:645-52.

58 Perez-Perez GI, Brown WR, Cover TL, et al. Correlation between serological and mucosal inflammatory responses to Helicobacter pylori. Clin Diagn Lab Immunol 1994;1:325-9.

59 Cover TL, Dooley CP, Blaser MJ. Characterization of and human serologic response to proteins in Helicobacter pylori broth culture supernatants with vacuolizing cytotoxin activity. Infect Immun 1990;58:603-10.

60 Covacci A, Censini S, Bugnoli M, et al. Molecular characterisation of the $128 \mathrm{kDa}$ immunodominant antigen of Helicobacter pylori associated with 128kDa immunodominant antigen of Helicobacter pylori associated with

61 Graham DY, Genta RM, Graham DP, et al. Serum CagA antibodies in asymptomatic subjects and patients with peptic ulcer: lack of correlation of IgG antibody in patients with peptic ulcer or asymptomatic Helicobacter pylori gastritis. F Clin Pathol 1996;49:829-32.

62 Heikkinen M, Mayo K, Megraud F, et al. Association of CagA-positive and CagA-negative Helicobacter pylori strains with patients' symptoms and gastritis in primary care patients with functional upper abdominal complaints. Scand f Gastroenterol 1998;33:31-8.

63 Parsonnet J, Friedman GD, Orentreich N, et al. Risk for gastric cancer in people with CagA positive or CagA negative Helicobacter pylori infection. Gut 1997;40:297-301.

64 Ferrero RL, Thiberge JM, Huerre M, et al. Recombinant antigens prepared from the urease subunits of Helicobacter spp.: evidence of protection in a mouse model of gastric infection. Infect Immun 1994;62:4981-9.

65 Michetti P, Corthesy-Theulaz I, Davin C, et al. Immunization of BALB/c mice against Helicobacter felis infection with Helicobacter pylori urease. Gastroenterology 1994;107:1002-11.

66 Lee CK, Weltzin R, Thomas WD Jr, et al. Oral immunisation with recombinant Helicobacter pylori urease induces secretory IgA antibodies and protects mice from challenge with Helicobacter felis. F Infect Dis 1995; 172:161-2.

67 Cuenca R, Blanchard TG, Czinn SJ, et al. Therapeutic immunization against Helicobacter mustelae in naturally infected ferrets. Gastroenterology 1996;110:1770-5.

68 Gomez-Duarte OG, Lucas B, Yan ZX, et al. Protection of mice against gastric colonization by Helicobacter pylori by single oral dose immunization with attenuated Salmonella typhimurium producing urease subunits $\mathrm{A}$ and B. Vaccine 1998;16:460-71.

69 Marchetti M, Rossi M, Giannelli V, et al. Protection against Helicobacter pylori infection in mice by intragastric vaccination with $\mathrm{H}$. pylori antigens is achieved using a non-toxic mutant of E. coli heat-labile enterotoxin (LT) as adjuvant. Vaccine 1998;16:33-7.

70 Kleanthous H, Myers GA, Georgakopoulos KM, et al. Rectal and intranasal immunizations with recombinant urease induce distinct local and serum immune responses in mice and protect against Helicobacter pylori infection. Infect Immun 1998;66:2879-86.

71 Ferrero RL, Thiberge JM, Kansau I, et al. The GroES homolog of Helicobacter pylori confers protective immunity against mucosal infection in mice. Proc Natl Acad Sci USA 1995;92:6499-503.

72 Ghiara $\mathrm{P}$, Rossi M, Marchetti M, et al. Therapeutic intragastric vaccination against Helicobacter pylori in mice eradicates an otherwise chronic infection and confers protection against reinfection. Infect Immun 1997;65: 4996-5002.

73 McAtee CP, Lim MY, Fung K, et al. Identification of potential diagnostic and vaccine candidates of Helicobacter pylori by two-dimensional gel electrophoresis, sequence analysis, and serum profiling. Clin Diagn Lab Immunol 1998;5:537-42.

74 Hook-Nikanne J, Perez-Perez GI, Blaser MJ. Antigenic characterisation of Helicobacter pylori strains from different parts of the world. Clin Diagn Lab Immunol 1997;4:592-7.

75 Crabtree JE, Farmery SM. Helicobacter pylori and gastric mucosal cytokines: evidence that CagA-positive strains are more virulent. Lab Invest 1995;73:742-5.

76 van Eden W, van der Zee R, Paul AG, et al. Do heat shock proteins control the balance of T-cell regulation in inflammatory diseases? Immunol Today 1998;19:303-7.

77 Valnes K, Huitfeldt HS, Brandtzaeg P. Relation between T cell number and epithelial HLA class II expression quantified by image analysis in normal and inflamed human gastric mucosa. Gut 1990;31:647-52.

78 Seifarth C, Deusch K, Reich K, et al. Local cellular immune response in Helicobacter pylori associated type B gastritis-selective increase of CD4 but not gamma delta T-cells in the immune response to $\mathrm{H}$. pylori antigens. $Z$ Gastroenterol 1996;34:215-24.

79 Engstrand L, Scheynius A, Pahlson C, et al. Association of Campylobacter pylori with induced expression of class II transplantation antigens on gastric epithelial cells. Infect Immun 1989;57:827-32.

80 Papadimitriou CS, Ioachim-Velogianni EE, Tsianos EB, et al. Epithelial HLA-DR expression and lymphocyte subsets in gastric mucosa in type B HLA-DR expression and lymphocyte subsets in gast
chronic gastritis. Virchows Arch 1988;413:197-204.

81 Ye G, Barrera C, Fan X, et al. Expression of B7-1 and B7-2 costimulatory molecules by human gastric epithelial cells: potential role in CD4 $4^{+} \mathrm{T}$ cell activation during Helicobacter pylori infection. F Clin Invest 1997;99:1628-

82 Harris PR, Mobley HL, Perez-Perez GI, et al. Helicobacter pylori urease is a potent stimulus of mononuclear phagocyte activation and inflammatory cytokine production. Gastroenterology 1996;111:419-25.

83 Oberhuber G, Bodingbauer M, Mosberger I, et al. High proportion of granzyme B-positive (activated) intraepithelial and lamina propria lymphocytes in lymphocytic gastritis. Am f Surg Pathol 1998;22:450-8.

84 Agnihotri N, Bhasin DK, Vohra $\mathrm{H}$, et al. Characterisation of lymphocytic subsets and cytokine production in gastric biopsy samples

85 Bamford KB, Fan X, Crowe SE, et al. Lymphocytes in the human gastric mucosa during Helicobacter pylori have a T helper cell 1 phenotype. Gastroenterology 1998;114:482-92.

86 Hatz RA, Meimarakis G, Bayerdorffer E, et al. Characterization of lymphocytic infiltrates in Helicobacter pylori-associated gastritis. Scand $\mathcal{F}$ Gastroenterol 1996;31:222-8.
87 Kaye MD, Whorwell PJ, Wright R. Gastric mucosal lymphocyte subpopulations in pernicious anemia and in normal stomach. Clin Immunol Immunopathol 1983;28:431-40.

88 Carmel R, Boone D, Parker JW. Lymphocyte surface phenotypes in pernicious anemia. Dig Dis Sci 1987;32:846-50.

89 Trejdosiewicz LK, Calabrese A, Smart CJ, et al. Gamma delta T cell receptor-positive cells of the human gastrointestinal mucosa: occurrence and $\mathrm{V}$ region gene expression in Heliobacter pylori-associated gastritis, coeliac disease and inflammatory bowel disease. Clin Exp Immunol 1991;84:440-4.

90 Fan XJ, Long A, Fan X, et al. Adhesion molecule expression on gastric intra-epithelial lymphocytes of patients with Helicobacter pylori infection. Eur $\mathcal{F}$ Gastroenterol Hepatol 1994;7:541-6.

91 Kelleher D, Murphy A, Lynch S, et al. Adhesion molecules utilized in binding of intraepithel

92 Fan XI, Chua A, Shahi CN, et al Gastric T lymphocyte responses to Helicobacter pylori in patients with $\mathrm{H}$ pylori colonisation. Gut 1994;35: 1379-84.

93 Karttunen R. Blood lymphocyte proliferation, cytokine secretion and appearance of $\mathrm{T}$ cells with activation surface markers in cultures with Helicobacter pylori. Comparison of the responses of subjects with an

$94 \mathrm{Di}$ Tommaso A, Xiang Z, Bugnoli M, et al. Helicobacter pylori-specific $\mathrm{CD} 4^{+} \mathrm{T}$-cell clones from peripheral blood and gastric biopsies. Infect Immun 1995;63:1102-6.

95 Karttunen R, Andersson G, Poikonen K, et al. Helicobacter pylori induces lymphocyte activation in peripheral blood cultures. Clin Exp Immunol 1990;82:485-8.

96 Birkholz S, Knipp U, Opferkuch W. Stimulatory effects of Helicobacter pylori on human peripheral blood mononuclear cells of $\mathrm{H}$. pylori

97 Hatz RA, Brooks WP, Andress H-J, et al. Specific suppression of the immune response of peripheral blood lymphocytes in Helicobacter pylori infection. Digestion 1991;49:18-9.

98 Sharma SA, Miller GG, Perez-Perez GI, et al. Humoral and cellular immune recognition of Helicobacter pylori proteins are not concordant. Clin Exp Immunol 1994;97:126-32.

99 Shahi CN, Fou XJ, Chua A, et al. Defective antigen-specific responses to Helicobacter pylori antigens in patients with gastric H. pylori colonisation. Ir F Med Sci 1992;161:54

100 Fan XG, Yakoob J, Fan XJ, et al. Enhanced T-helper 2 lymphocyte responses: Immune mechanism of Helicobacter pylori infection. Ir $\mathcal{F} \mathrm{Med}$ Sci 1994;165:37-9.

101 Duchmann R, Scherer H, Neurath M, et al. Normal interleukin-12 production in individuals with antibodies to Helicobacter pylori. APMIS 1997;105:824-30.

102 Sharma SA, Miller GG, Peek RA Jr, et al. T-cell, antibody, and cytokine responses to homologs of the 60-kilodalton heat shock protein in Helicobacter pylori infection. Clin Diagn Lab Immunol 1997;4:440-6.

103 D'Elios MM, Manghetti M, De Carli M, et al. T helper 1 effector cells specific for Helicobacter pylori in the gastric antrum of patients with peptic ulcer disease. F Immunol 1997;158:962-7.

104 D'Elios MM, Manghetti M, Almerigogna F, et al. Different cytokine profile and antigen-specificity repertoire in Helicobacter pylori-specific $\mathrm{T}$ cell clones from the antrum of chronic gastritis patients with or without peptic ulcer. Eur F Immunol 1997;27:1751-5.

105 Good MF, Zevering Y, Currier J, et al. 'Original antigenic sin', T cell memory, and malaria sporozoite immunity: an hypothesis for immune evasion. Parasite Immunol 1993;15:187-93.

106 Zevering Y, Amante F, Smillie A, et al. High frequency of malaria-specific $\mathrm{T}$ cells in non-exposed humans. Eur F Immunol 1992;22:689-96.

107 Currier J, Sattabongkot J, Good MF. 'Natural' T cells responsive to malaria: evidence implicating immunological cross-reactivity in the maintenance of TCR alpha beta $^{+}$malaria-specific responses from non-exposed donors. Int Immunol 1992;4:985-94.

108 Zevering Y, Khamboonruang C, Good MF. Human and murine T-cell responses to allelic forms of a malaria circumsporozoite protein epitope support a polyvalent vaccine strategy. Immunology 1998;94:445-54.

109 Klenerman P, Zinkernagel RM. Original antigenic sin impairs cytotoxic $\mathrm{T}$ lymphocyte responses to viruses bearing variant epitopes. Nature 1998;394:

110 Ihan A, Tepez B, Kavcic I, et al. IL-2 receptor expression on gastric mucosa T lymphocytes is enhanced in duodenal ulcer patients compared with nonulcer dyspeptic patients. Hepatogastroenterology 1996;43:1665-70.

111 Koulis A, Diss T, Isaacson PG, et al. Characterization of tumor-infiltrating $\mathrm{T}$ lymphocytes in B-cell lymphomas of mucosa-associated lymphoid tissue. Am F Pathol 1997;151:1353-60.

112 Hussell T, Isaacson PG, Crabtree JE, et al. The response of cells from lowgrade B-cell gastric lymphomas of mucosa-associated lymphoid tissue to Helicobacter pylori. Lancet 19934;342:571-4.

113 Hussell T, Isaacson PG, Crabtree JE, et al. Helicobacter pylori-specific tumour-infiltrating $\mathrm{T}$ cells provide contact dependent help for the growth of malignant B cells in low-grade gastric lymphoma of mucosa-associated lymphoid tissue. F Pathol 1996;178:122-7.

114 Greiner A, Knorr C, Qin Y, et al. Low-grade B cell lymphomas of mucosaassociated lymphoid tissue (MALT-type) require CD40-mediated signaling and Th2-type cytokines for in vitro growth and differentiation. Am $\mathcal{F}$ Pathol

115 Romagnani S. Th1 and Th2 in human diseases. Clin Immunol Immunopathol 1996;80:225-35.

116 Mosmann TR, Sad S. The expanding universe of T-cell subsets: Th1, Th2 and more. Immunol Today 1996;17:138-46.

117 Nielsen H, Andersen LP. Activation of phagocytes by Helicobacter pylori correlates with the clinical presentation of the gastric infection. Scand $\mathcal{F}$ Infect Dis 1995;27:347-50.

118 Wagner S, Beil W, Westermann J, et al. Regulation of gastric epithelial cell growth by Helicobacter pylori: evidence for a major role of apoptosis. Gastroenterology 1997;113:1836-47.

119 Wilson KT, Ramanujam KS, Mobley HL, et al. Helicobacter pylori stimulates inducible nitric oxide synthase expression and activity in a murine macrophage cell line. Gastroenterology 1996;111:1524-33.

120 Mooney C, Keenan J, Munster D, et al. Neutrophil activation by Helicobacter pylori. Gut 1991;32:853-7. 
121 Peek RM Jr, Miller GG, Tham KT, et al. Heightened inflammatory response and cytokine expression in vivo to cag $\mathrm{A}^{+}$Helicobacter pylori 2 Haberle HA, Kubin

M, Bamford KB, et al. Differential stimulation of interleukin-12 (IL-12) and IL-10 by live and killed Helicobacter pylori in vitro and association of IL-12 production with gamma interferonproducing $\mathrm{T}$ cells in the human gastric mucosa. Infect Immun 1997;65: 4229-35.

123 Yamaoka Y, Kita M, Kodama T, et al. Expression of cytokine mRNA in gastric mucosa with Helicobacter pylori infection. Scand 7 Gastroenterol 1995;30:1153-9.

124 Karttunen R, Karttunen T, Ekre HP, et al. Interferon gamma and interleukin 4 secreting cells in the gastric antrum in Helicobacter pylori positive and negative gastritis. Gut 1995;36:341-5.

125 Karttunen RA, Karttunen TJ, Yousfi MM, et al. Expression of mRNA for interferon-gamma, interleukin-10, and interleukin-12 (p40) in normal gastric mucosa and in mucosa infected with Helicobacter pylori. Scand $\mathcal{F}$ Gastroenterol 1997;32:22-7.

126 Sommer F, Faller G, Konturek P, et al. Antrum- and corpus mucosa-infiltrating CD4 $(+)$ lymphocytes in Helicobacter pylori gastritis mucosa-infiltrating CD4(+) lymphocytes in Helicobacter

127 Lindholm C, Quiding-Jarbrink M, Lonroth $\mathrm{H}$, et al. Local cytokine response in Helicobacter pylori-infected subjects. Infect Immun 1988;66: 5964-71

128 Bodger K, Wyatt JI, Heatley RV. Gastric mucosal secretion of interleukin10: Relations to histopathology, Helicobacter pylori status, and tumour necrosis factor-alpha secretion. Gut 1997;40:739-44.

129 Chakrabarti D, Hultgren B, Stewart TA. IFN-alpha induces autoimmune $\mathrm{T}$ cells through the induction of intracellular adhesion molecule-1 and B7.2. F Immunol 1996;157:522-8.

130 Aderka D, Le JM, Vilcek J. IL-6 inhibits lipopolysaccharide-induced tumor necrosis factor production in cultured human monocytes, U937 cells, and in mice. F Immunol 1989;143:3517-23.

131 Crabtree JE, Shallcross TM, Heatley RV, et al. Mucosal tumour necrosis factor alpha and interleukin-6 in patients with Helicobacter pylori associated gastritis. Gut 1991;32:1473-7.

132 Letterio JJ, Roberts AB. Regulation of immune responses by TGF-beta. Annu Rev Immunol 1998;16:137-61.
133 Hamann D, Hilkens CM, Grogan JL, et al. CD30 expression does not discriminate between human Th1- and Th2-type $\mathrm{T}$ cells. $\mathcal{f}$ Immunol criminate between

134 Barnard A, Mahon BP, Watkins J, et al. Th1/Th2 cell dichotomy in acquired immunity to Bordetella pertussis: variables in the in vivo priming and in vitro cytokine detection techniques affect the classification of T-cell subsets as Th1, Th2 or Th0. Immunology 1996;87:372-80.

135 Saldinger PF, Porta N, Launois P, et al. Immunization of BALB/c mice with Helicobacter urease B induces a T helper 2 response absent in Helicobacter infection. Gastroenterology 1998;115:891-7.

136 Guy B, Hessler C, Fourage S, et al. Systemic immunization with urease protects mice against Helicobacter pylori infection. Vaccine 1998;16:850-6.

137 Fratazzi C, Guerriero M, Carini C. Interleukin 7 and sCD23 synergize in the induction of human $\mathrm{T}$ cell activation in HIV-1-infected subjects. Int Arch Allergy Immunol 1997;114:120-9.

138 Mehrotra PT, Grant AJ, Siegel JP. Synergistic effects of IL-7 and IL-12 on human T cell activation. F Immunol 1995;154:5093-102.

139 Gessner A, Will A, Vieth M, et al. Stimulation of B-cell lymphopoiesis by interleukin-7 leads to aggravation of murine leishmaniasis. Immunology 1995;84:416-22.

140 Leong KH, Ramshaw IA, Ramsay AJ. Interleukin-7 enhances cellmediated immune responses in vivo in an interleukin-2-dependent manner. Viral Immunol 1997;10:1-9.

141 Carini C, Essex M. Interleukin 2-independent interleukin 7 activity enhances cytotoxic immune response of HIV-1-infected individuals. AIDS Res Hum Retroviruses 1994;10:121-30.

142 Michetti P. Vaccine against Helicobacter pylori: fact or fiction. Gut 1997;41:728-30.

143 Blaser MJ. Helicobacter pylori and gastric diseases. BMF 1998;316:1507-10.

144 Labenz J, Blum AL, Bayerdorffer E, et al. Curing Helicobacter pylori infection in patients with duodenal ulcer may provoke reflux esophagitis. Gastroenterology 1997;112:1442-7.

145 Schutze K, Hentschel E, Dragosics B, et al. Helicobacter pylori reinfection with iden

146 Chow WH, Blaser MJ, Blot WJ, et al. An inverse relation between cagA+ strains of Helicobacter pylori infection and risk of esophageal and gastric cardia adenocarcinoma. Cancer Res 1998;58:588-90. 